\title{
Plasma, Intestine and Tumor Levels of 5-Fluorouracil in Mice Bearing L1210 Ascites Tumor Following Oral Administration of 5-Fluorouracil, UFT (Mixed Compound of Tegafur and Uracil), Carmofur and 5'-Deoxy-5-fluorouridine
}

\author{
Kazuya Ooi, ${ }^{*, a}$ Toshiki Ohkubo, ${ }^{b}$ Masamune Higashigawa, ${ }^{b}$ Hajime Kawasaki, ${ }^{b}$ Hideshi Kakito, ${ }^{c}$ \\ Yoshiyuki Kagawa, ${ }^{c}$ Michio KoJima, ${ }^{c}$ and Minoru SaKurai ${ }^{b}$ \\ Department of Pharmacy, Yokkaichi Social Insurance Hospital, ${ }^{a}$ 10-8 Hazuyama-cho, Yokkaichi 510-0016, Japan and \\ Department of Pediatrics, ${ }^{b}$ Department of Pharmacy, ${ }^{\mathrm{c}}$ Mie University School of Medicine, 2-174 Edobashi, Tsu 514-0001, \\ Japan. Received May 23, 2001; accepted August 27, 2001
}

Several 5-fluorouracil (5-FU) derivatives, 1-hexylcarbamoyl-5-fluorouracil (HCFU), 5'-deoxy-5-fluorouridine (5'-DFUR) and UFT (mixed compound of tegafur and uracil), have been developed and clinically widely used. However, comparative pharmacokinetic studies of the parent compound and other fluorinated drivatives have not been precisely reported. The dosage of the oral clinical use for human cancer of 5-FU, HCFU, $5^{\prime}$-DFUR and UFT as tegafur (FT) is $200-300 \mathrm{mg} / \mathrm{d}, 600 \mathrm{mg} / \mathrm{d}, 800-1200 \mathrm{mg} / \mathrm{d}$ and $300-600 \mathrm{mg} / \mathrm{d}$ respectively. These amounts of the drugs are almost equimolar. Previously, we reported the effect of oral equimolar administration of each four drugs on thymidilate synthase activity, deoxyribonucleotide metabolism and cell cycle progression in L1210 ascites tumor. ${ }^{1,2)}$ In this study, we examined the antitumor effect and 5-FU concentration in the plasma, intestine and tumor after oral equimolar administrations of each drug using BDF1 mice bearing L1210 ascites tumor. In our study, UFT showed the best life prolongation among these four drugs. The intestine 5-FU level was highest by treatment with 5-FU during the initial $4 \mathrm{~h}$. The plasma 5-FU level was highest by treatment with HCFU for $4 \mathrm{~h}$. But the tumor 5-FU level was highest by treatment with UFT over the $24 \mathrm{~h}$. In spite of the high plasma 5-FU concentration after the treatment with HCFU, the 5-FU concentration in the tumor was below the detectable level until $24 \mathrm{~h}$. These findings suggested that the highest specific accumulation of 5-FU in tumor cells may explain the best therapeutic results of UFT.

Key words 5-fluorouracil; tegafur; UFT; 5'-deoxy-5-fluorouridine; 1-hexylcarbamoyl-5-fluorouracil; antitumor activity

5-Fluorouracil (5-FU), synthesized in 1956 by Duschinsky and Heidelberger is an intensively examined anticancer drug for use in clinical cancer chemotherapy. ${ }^{3-5)} 5$-FU and its analogues have been shown to be effective for the treatment of human cancers. ${ }^{6-8)}$ 1-(2-Tetrahydrofuryl)-5-fluorouracil (FT), 1-hexylcarbamoyl-5-fluorouracil (HCFU) and 5'deoxy-5-fluorouridine (5'-DFUR) are synthetic derivatives of $5-\mathrm{FU} .^{9-13)}$ UFT is a mixed compound of tegafur and uracil at a ratio of $1: 4{ }^{14)} \mathrm{FT}$ is converted to 5 -FU by the microsomal fraction (P-450) of liver in the presence of NADPH. ${ }^{15)}$ Uracil enhances the antitumor activity of tegafur by inhibiting the degradation of 5-FU generated from tegafur. Uracil suppresses the degradation of 5-FU but does not inhibit the phosphorylation of 5-FU. ${ }^{14,16,17)} 5^{\prime}$-DFUR is converted to 5FU in mainly the tumor and intestine by uridine phosphorylase in mice and by thymidine phosphorylase in humans. HCFU, lipophilic analogue of 5-FU is absorbed rapidly in an intact form through the gastrointestinal tract and distributed into the tumor. HCFU is converted to 5-FU by natural degradation.

These compounds were developed to obtain the selective accumulation of 5-FU in the tumor. In this study, we compared these 4 compounds measuring their antitumor effect and 5-FU concentration in the plasma, intestine and tumor.

\section{MATERIALS AND METHODS}

Anticancer Drugs and Chemicals UFT was obtained from Taiho Pharmaceutical Co., Ltd. (Tokushima, Japan), and 5-FU, HCFU and 5'-DFUR were purchased from
Nacalai Tesque Inc. (Kyoto, Japan), Mitsui Pharmaceutical Inc. (Tokyo, Japan) and Nippon Roche Co., Ltd. (Tokyo), respectively. All other substances were analytical-grade reagents.

Mice and Tumor Male BDF1 mice weighing from 20 to $22 \mathrm{~g}$ each were kept at the Mie University Animal Center under constant conditions ( $12 \mathrm{~h}$ light: dark regimen, Oriental Chow pellet food and water ad libitum). The mice used for these experiments were 8 weeks of age. L1210 cells were maintained in BDF1 mice by weekly intraperitoneal (i.p.) injections of $1 \times 10^{6}$ cells. Mice used in the experiment received $1 \times 10^{6}$ ascites tumor cells i.p. The mice were divided into five groups. Each group consisted of 10 mice. Only water was given to the mice during the $12 \mathrm{~h}$ before drug administration. The cells were harvested by washing the mouse peritoneal cavity with $1 \mathrm{ml}$ of ice-cold phosphate buffered saline (PBS). To evaluate the life prolongation effect, each drug was given orally for five consecutive days (twice daily) after the tumor inoculation.

To measure the plasma, tumor and intestine levels of 5-FU, a single dose of each drug was given orally $3 \mathrm{~d}$ after the tumor inoculation $(n=3)$.

Doses of the Drugs The doses of 5-FU, UFT, HCFU and $5^{\prime}$-DFUR were $13 \mathrm{mg} / \mathrm{kg}, 64.8 \mathrm{mg} / \mathrm{kg}(20 \mathrm{mg} / \mathrm{kg}$ of tegafur and $44.8 \mathrm{mg} / \mathrm{kg}$ of uracil), $25.7 \mathrm{mg} / \mathrm{kg}$ and $24.6 \mathrm{mg} / \mathrm{kg}$ respectively. These doses were equimolar to 5-FU.

Antitumor Activity Antitumor activity was evaluated by calculating the prolongation of the postinoculation lifespan (percentage ILS).

Determination of 5-FU Concentration in Intestine, 
Plasma and Tumor On day 3 after the tumor inoculation, a single dose of drug was orally administered. The mice were killed at various intervals and the plasma and other tissues were removed. The ascites cells were harvested by washing the mice peritoneal cavity with $1 \mathrm{ml}$ of ice-cold phosphatebuffered saline and centrifuged at $1500 \mathrm{rpm}$ for $5 \mathrm{~min}$ at $4{ }^{\circ} \mathrm{C}$. The viavility of the tumor cells by dye exclusion test was higher than $95 \%$ at $24 \mathrm{~h}$.

The samples were then stored at $-20^{\circ} \mathrm{C}$ in the dark until analysis. The separation of 5-FU from the plasma, intestine and the tumor was carried out as reported previously. ${ }^{18)}$

The gas chromatography-mass fragmentography apparatus and conditions for determination of 5-FU was reported previously. ${ }^{18)}$ Student's $t$-test was used for statistical analysis.

\section{RESULTS}

Effect of Equimolar Oral Administration of 5-FU, UFT, HCFU and 5'-DFUR on the Survival of L1210 Ascites Tumor Bearing BDF1 Mice The lifespan of mice treated with 5-FU, UFT, HCFU, or 5'-DFUR was extended significantly by $12.2 \mathrm{~d}, 15.0 \mathrm{~d}, 10.7 \mathrm{~d}$ and $9.3 \mathrm{~d}$, respectively. UFT had the most potent antitumor activity when the equimolar drugs were administered orally (Table 1). Based on the weight loss of the mice, the 4 drugs were concluded to have similar degrees of toxicity. No death due to toxic effects was observed.

5-FU Levels in the Intestine, Plasma, and Tumor after Oral Administration of the Four Fluorinated Pyrimidines 5-FU levels in the intestine were higher than those in the plasma (Figs. 1, 2). Intestinal 5-FU concentration in intestine (Fig. 2) was highest for the treatment with 5-FU during the initial $4 \mathrm{~h}$ and lowest for UFT at $0.5 \mathrm{~h}$. Area under the curve $(A U C)$ in intestine treated with 5-FU, UFT, HCFU 5'-DFUR were $6531 \mathrm{ng} \cdot \mathrm{h} / \mathrm{g}, 5676 \mathrm{ng} \cdot \mathrm{h} / \mathrm{g}, 2995 \mathrm{ng} \cdot \mathrm{h} / \mathrm{g}, 3101 \mathrm{ng} \cdot \mathrm{h} / \mathrm{g}$ respectively.

The plasma concentration of 5-FU after administration of HCFU was significantly higher than the other drugs for the initial $2 \mathrm{~h}$. It reached a maximum at $30 \mathrm{~min}$ after treatment and then disappeared relatively rapidly from the plasma. Plasma 5-FU levels after 5-FU and 5'-DFUR were lower than $100 \mathrm{ng} / \mathrm{ml}$ at $30 \mathrm{~min}$ and were below the detectable level after $1 \mathrm{~h}$ (Fig. 2). AUC in plasma treated with 5-FU, UFT, HCFU $5^{\prime}$-DFUR were $55 \mathrm{ng} \cdot \mathrm{h} / \mathrm{g}, \quad 515 \mathrm{ng} \cdot \mathrm{h} / \mathrm{g}, \quad 1118 \mathrm{ng} \cdot \mathrm{h} / \mathrm{g}, \quad 45$ $\mathrm{ng} \cdot \mathrm{h} / \mathrm{g}$ respectively. The time-concentration changes in the tumor 5-FU level are shown in Fig. 3. Tumor 5-FU concentrations for the treatment with UFT were higher than $200 \mathrm{ng} / \mathrm{ml}$ for $24 \mathrm{~h}$. Tumor levels of $5-\mathrm{FU}$ by treatment with 5 -FU were higher than $50 \mathrm{ng} / \mathrm{ml}$ at 2 and $4 \mathrm{~h}$. Tumor levels of

Table 1. Effect of Administration of Fluoropyrimidines on the Survival of Mice Bearing L1210 Leukemia

\begin{tabular}{lcc}
\hline \hline Treatment & Mean survival \pm S.D. (d) & (\%) ILS over control \\
\hline Control & $7.2 \pm 0.3$ & \\
5'-DFUR & $9.3 \pm 0.7$ & 29.2 \\
HCFU & $10.7 \pm 1.0$ & 48.6 \\
5-FU & $12.2 \pm 0.9$ & 69.4 \\
UFT & $15.0 \pm 2.2$ & 108.3 \\
\hline
\end{tabular}

BDF1 mice were intraperitoneally inoculated with L1210 cells. 5-FU $(13 \mathrm{mg} / \mathrm{kg})$, UFT $\left(64.8 \mathrm{mg} / \mathrm{kg}, 20 \mathrm{mg} / \mathrm{kg}\right.$ as tegafur), HCFU $(25.7 \mathrm{mg} / \mathrm{kg})$ or $5^{\prime}$-DFUR $(24.6 \mathrm{mg} / \mathrm{kg})$ was orally administered twice a day after tumor inoculation. ILS: increase of lifespan.

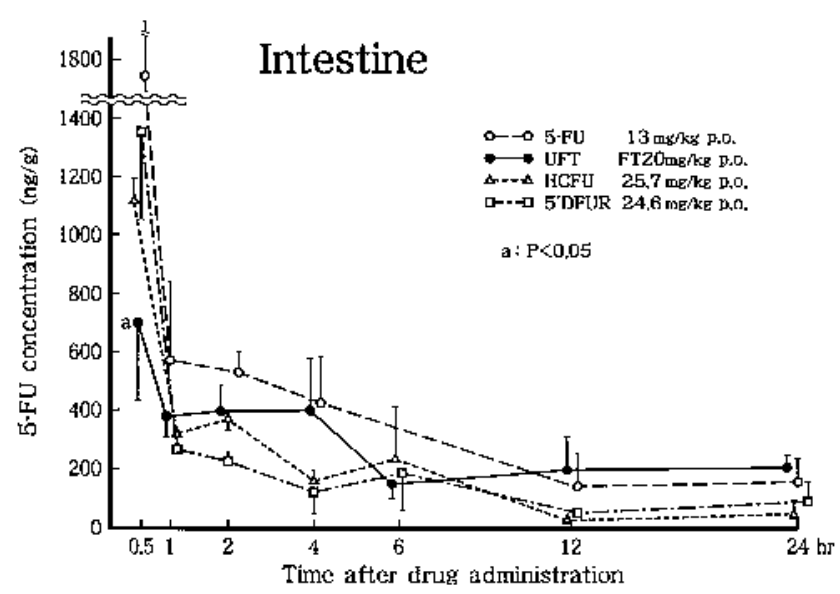

Fig. 1. Intestine Levels of 5-FU after Oral Administration of 5-FU, UFT, HCFU and 5'-DFUR to Mice Bearing L1210 Ascites Tumor

5 -FU $(13 \mathrm{mg} / \mathrm{kg})$, UFT $(20 \mathrm{mg} / \mathrm{kg}$ as tegafur $)$, HCFU $(25.7 \mathrm{mg} / \mathrm{kg})$ or $5^{\prime}$-DFUR $(24.6 \mathrm{mg} / \mathrm{kg}$ ) was orally administered on day 3 after the tumor inoculation. (a): Significantly different from the values of the 5 -FU treatment group.

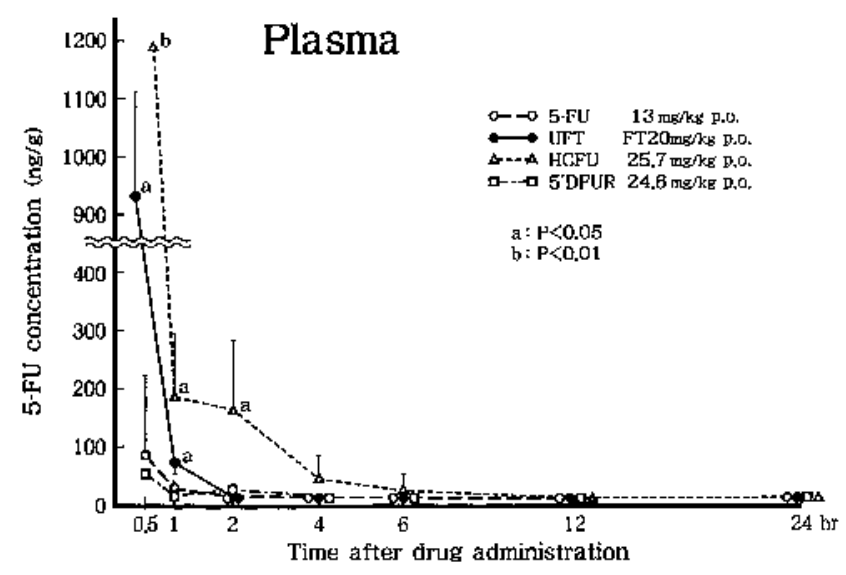

Fig. 2. Plasma Levels of 5-FU after Oral Administration of 5-FU, UFT, HCFU and 5'-DFUR to Mice Bearing L1210 Ascites Tumor

5 -FU $(13 \mathrm{mg} / \mathrm{kg})$, UFT $(20 \mathrm{mg} / \mathrm{kg}$ as tegafur $)$ HCFU $(25.7 \mathrm{mg} / \mathrm{kg})$ or $5^{\prime}$-DFUR $(24.6 \mathrm{mg} / \mathrm{kg}$ ) was orally administered on day 3 after the tumor inoculation. (a), (b): Significantly different from the values of the 5 -FU treatment group.

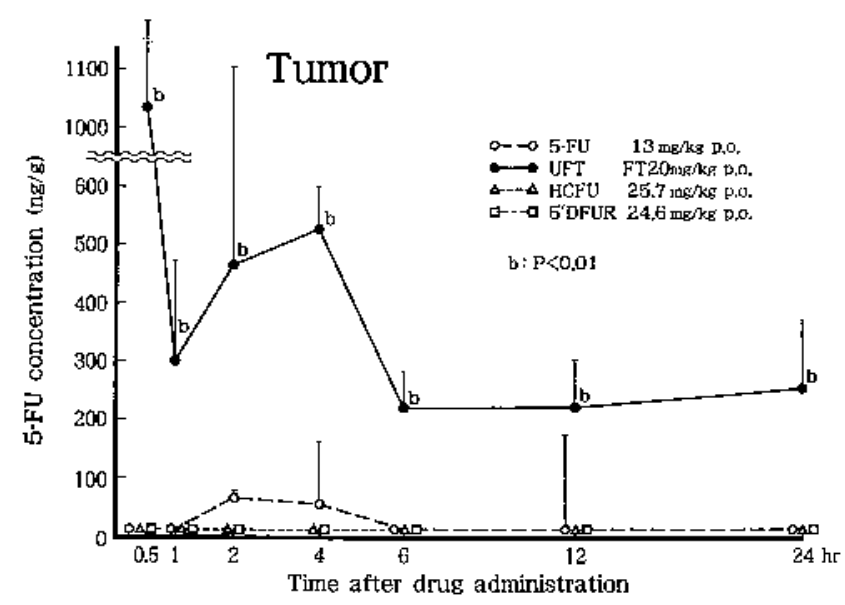

Fig. 3. Tumor Levels of 5-FU after Oral Administration of 5-FU, UFT, HCFU and 5'-DFUR to Mice Bearing L1210 Ascites Tumor

5 -FU $(13 \mathrm{mg} / \mathrm{kg})$, UFT $\left(20 \mathrm{mg} / \mathrm{kg}\right.$ as tegafur), HCFU $(25.7 \mathrm{mg} / \mathrm{kg})$ and $5^{\prime}$-DFUR $(24.6 \mathrm{mg} / \mathrm{kg}$ ) was orally administered on day 3 after the tumor inoculation. (b): Significantly different from the values of the 5 -FU treatment group. 
5-FU by HCFU and 5 -DFUR were below the detectable level for $24 \mathrm{~h}$. $A U C$ in tumor treated with 5-FU, UFT were $1037 \mathrm{ng} \cdot \mathrm{h} / \mathrm{g}, 6720 \mathrm{ng} \cdot \mathrm{h} / \mathrm{g}$ respectively.

\section{DISCUSSION}

Many experimental studies have shown that 5-FU derivatives have a broad antitumor spectrum. ${ }^{1,2,6,7,14)}$ They have been used clinically by oral administration. ${ }^{19)}$ In this study, we examined the antitumor effect and 5-FU concentration in the intestine, plasma and tumor after oral equimolar administrations of each drug using BDF1 mice bearing L1210 ascites tumor. Although all the drugs tested extended the life span of the experimental mice, only UFT showed a better therapeutic result than the parent compound, 5-FU. The intestinal 5-FU concentration was highest by treatment with 5-FU.

Tumor 5-FU concentration by $5^{\prime}$-DFUR treatment was very low. Ishitsuka et al. reported that uridine phosphorylase activity was low in L1210 cells. ${ }^{20)}$ This might be the reason why the tumor 5-FU concentration was very low by $5^{\prime}$ DFUR treatment. In spite of the high 5-FU plasma concentration, the tumor 5-FU concentration by HCFU treatment was below the detectable level throughout the $24 \mathrm{~h}$ period. The reason for this is now unknown.

Tumor 5-FU concentration was extremely high by UFT treatment. At 4 and $6 \mathrm{~h}$ after UFT administration, uracil concentration in the tumor increased to 133 and $189 \%$ of the control (data not shown). This increased uracil concentration might cause the 5-FU accumulation in the tumor by the competition of the breakdown pathway of 5-FU. ${ }^{17}$

In this study, the intestine and plasma concentrations of 5FU did not show any correlation with the antitumor effect. The tumor concentration of 5-FU might be a good indicator of the antitumor effect. In clinical use 5-FU and it's analogues are used for longer than several months. ${ }^{6}$ ) In this study, we examined the 5-FU concentrations after single administration of the drugs. Pharmacokinetic of these drugs after long term administration must be examined.

\section{REFERENCES}

1) Kakito H., Ohkubo T., Kagawa Y., Inagaki S., Sumida K., Ooi K., Higashigawa M., Sakurai M., Cancer Invest., 11, 530_533 (1993).

2) Kagawa Y., Ohkubo T., Higashigawa M., Ido M., Kakito H., Inagaki S., Kojima M., Ooi K., Sakurai M., Cancer Invest., 13, 470-474 (1995).

3) Duschinsky R., Pleven F., Heidelberger C., J. Am. Chem. Soc., 79, 4559-4560 (1967).

4) Heidelberger C., Griesbach L., Montag B. J., Mooren D., Cruz O., Cancer Res., 18, 305-317 (1958).

5) Yamada Y., Sakata Y., Tsushima K., Satoh T., Int. J. Clin. Oncol., 2, 10-14 (1997).

6) Kusunoki M., Yanagi H., Noda M., Yoshikawa R., Yamamura T., Cancer, 89, 1228-1235 (2000).

7) Kusunoki M., Yanagi H., Noda M., Yamamura T., Oncol. Rep., 6, 547-552 (1999).

8) Fujii S., Fukushima M., Shimamoto Y., Shirasaka T., Jpn. J. Cancer Res., 80, 509-512 (1989).

9) Hiller S. A., Zhuk R. A., Lidak M. J., Zidermane A. A., Patent specification 1168391., Br. Patent No. 1., 391-395 (1968).

10) Cook A. F., Holman M. J., Kramer M. J., Trown P. W., J. Med. Chem., 22, 1330-1335 (1979).

11) Koizumi W., Kurihara M., Sasai T., Yoshida S., Morise K., Imamura A., Akazawa S., Betsuyaku T., Ohkubo S., Takahashi H., Akiya T., Hamada T., Kiyohashi A., Cancer, 72, 658-662 (1993).

12) Takiguchi N., Nakajima N., Saitoh N., Fujimoto S., Nakazato H., Int. J. Oncol., 16, 1021-1027 (2000).

13) Kondo K., Sakamoto J., Nakazato H., Koike A., Kitoh T., Hachisuka K., Yura J., Nimura Y., Hamajima N., Katoh K., Yamaguchi A., Miya K., Yamauchi M., Mizuno I., Nagino M., Takagi H., Oncol. Rep., 7, 485-490 (2000).

14) Fujii S., Ikenaka K., Fukushima M., Shirasaka T., Gann, 69, 763-772 (1978).

15) Toide H., Akiyoshi H., Minato Y., Okuda H., Fujii S., Gann, 68, 553560 (1977).

16) Ikenaka K., Shirasaka T., Kitano S., Fujii S., Gann, 70, 353-359 (1979).

17) Takiuchi H., Ajani J. A., J. Clin. Oncol., 16, 2877-2885 (1998).

18) Marunaka T., Umeno Y., Yoshida K., Nagamachi M., Minami Y., Fujii S., J. Pharm. Sci., 69, 209-213 (1980).

19) Sulkes A., Benner Se., Canetta R. M., J. Clin. Oncol., 16, 3461-3475 (1998).

20) Ishitsuka H., Miwa M., Takemoto K., Fukuoka K., Itoga A., Maruyama H. B., Gann, 71, 112-123 (1980). 